\title{
Jane Eyre and its Heteroglossia, Colonialism, Class Struggle, Racial Otherness and the Significance of the British Empire
}

\author{
Partha Sarathi Mandal ${ }^{1}$, Preyona Bhowmik ${ }^{2}$, Debojyoti Roy ${ }^{3}$
}

${ }^{1} \mathrm{PhD}$ Research Scholar, Raiganj University and Faculty Member of the English Department, Lilabati Mahavidyalaya, West Bengal, India

${ }^{2,3}$ B.A. English Honours $4^{\text {th }}$ Semester Student, Lilabati Mahavidyalaya, West Bengal, India

\begin{abstract}
The assessment of colonialism which Jane Eyre promises to make through its correspondence between forms of oppression finally collapses into a mere restlessness about the effects of empire on domestic social relations in England. That disquietude is the only leftover of Bronte's potentially deep-seated revision of the analogy between white women and colonized races, and it is the only unfinished constituent in the ideological closure of the novel. The unsavoury mist which suggests British colonial contact with the racial "other," diffused throughout the ending of the novel, betrays Bronte's persistent anxiety about British colonialism and about her own literary handling of the racial "other," about the technique in which, through repressive metaphorical strategy, she has tried to formulate the world of Jane Eyre "clean."
\end{abstract}

Keywords - Colonialism, Empire, Racial, Oppression.

\section{INTRODUCTION}

Wake up, rise and shine

Let's get to work on time

No more playing video games

Things are about to change, 'round here, 'round here

$$
\begin{aligned}
& \text { — "Ain’t Your Mama" ( } \\
& \text { Jennifer Lopez) }
\end{aligned}
$$

Charlotte Brontein her early days and teenage years in the late 1820 s and 30 s wrote hundreds of pages of fiction set in a make-believe British colony in Africa. Her stories display some facts of African history and of the current history of British colonialism in Africa by making reference to the Ashanti Wars of the 1820s, it is also a fact that she uses the names of some real Ashanti leaders, and positions her colony near Fernando Po, which a writer for Blackwood's Magazine had been publically recommending as a pertinent mark for British colonization. ${ }^{1}$ Other outlooks of Bronte's adolescent

1 Christine Alexander, The Early Writings of Charlotte Bronte (Oxford: Basil Blackwell, 1983), p. 30. This work provides a detailed summary of the plots of Charlotte Brontejuvenile writings as well as an analysis of Charlotte Bronte's development as a writer as manifested in this early fiction. Alexander is currently working on an authoritative edition of the Charlotte juvenilia, the first volume of which has now been published as An Edition of the Early stories put forward her awareness of events in the British West Indies as well. Detailed tortures mechanised by West Indian planters on disobedient slaves become visible in Bronte's early fiction, portrayed on both black and white characters, and her most significant black character, Quashia Quamina, who strategically leads intermittent insurgency against her white colonists, bears the surname of the slave who took part in the Demerara unrest of 1823 in British Guiana - as well as a first name imitative of the racist appellation "Quashee." Colonialism is also in attendance and used symbolically - in each of Bronte's foremost novels. In both Shirley (1849) and Villette (1853) the guys whom the heroines love either depart or bully to leave Europe for spaces of European colonization, and both guys envision their associations with colonized people as standing in for their affairs with white women. Louis Moore in Shirley puts forward the idea of going to North America and lives with the Indians, and instantaneously advocates that he will obtain one of the "sordid savages," in place of Shirley, as his spouse. ${ }^{2} \mathrm{M}$. Paul goes away for the French West Indian colony of Guadeloupe at the end of Villette, to take care of

Writings of Charlotte Bronte: 1826-1832 (New York: Basil Blackwell, 1987).

2 Charlotte Bronte, Shirley (1849; rpt. New York: Oxford University Press, 1981), p. 613. 
an estate there in place of wedding Lucy. Nevertheless such an estate would without a doubt have required administration in the early 1850s, as the French slaves had just been liberated in 1848. Bronte postulates the turbulent situation of the colony by the finale she gives the novel: M. Paul may be slaughtered by one of the steamy thunder which Bronte, like writers as miscellaneous as Monk Lewis and Harriet Martineau, acquaintances with the wrath and the vengeance of the black West Indians. ${ }^{3}$ M. Paul appears to us as a white colonist, Lucy is like an indigenous resisting control: Bronte has Lucy imagine of her own artistic desires as a storm god, "a dark Baal." The novel's promising tragic ending becomes more indistinct on the level of these metaphors: it may not be wholly a tragedy if M. Paul is certainly destroyed by a storm and does not go back from dominating West Indian blacks to tie the knot with Lucy he calls "sauvage."4 In The Professor (1846), white women's confrontation with phallocentric power structure is more blatantly figured as "black." The novel starts as an unreceived letter, whose anticipated addressee has vanished into "a government appointment in one of the colonies." ${ }^{5}$ The individual succeeding acquaintances of William Crimsworth among the juvenile women of a Belgian pensionnat are showcased as ananalogousoperation of colonization. Crimsworth diplomatically juxtaposes his Belgian-Catholic girl pupils to blacks whom he must compulsorily maintain under supervision. He likens one Caroline, for instance, to a

\footnotetext{
${ }^{3}$ In "The Isle of Devils," a thinly disguised verse-narrative about race relations in the British West Indies, Lewis creates a horrible monster, "black as the storm," who rapes a beautiful white virgin after her ship is wrecked near his island during a tempest (Monk Lewis, "The Isle of Devils" [1815], in his Journal of a West India Proprietor [London: John Murray, 1834], pp. 261-287). In Martineau's antislavery novel, Demerara, a West Indian hurricane enacts the rage the slaves themselves cannot: the slaves in her novel exult at the ravages the storm commits on their master's property, cry out with "horrid yells" as they watch their overseer drowning, and seem "like imps of the storm" (in Harriet Martineau, Illustrations of Political Economy [London: Charles Fox, 1834], II, 109-112). Bronte uses similar imagery in her Roe Head Journal.

${ }^{4}$ Charlotte Bronte, Villette (1853; rpt. New York: Penguin Books, 1983), p. 404. For a discussion of the abolition of slavery in the French West Indian colonies, see F. R. Augier, S. C. Gordon, D. G. Hall, and M. Reckord, The Making of the West Indies (London: Longmans, 1960), pp. 200-201 and J. H. Parry and P. M. Sherlock, A Short History of the West Indies (New York: Macmillan, 1957), p. 219. Parry and Sherlock note that "the events of 1848-49, which marked the end of slavery, foreshadowed also the end of white political supremacy ... in Martinique and Gaudeloupe."

${ }^{5}$ Charlotte Bronte, The Professor, ed. Margaret Smith and Herbert Rosengarten (Oxford: Clarendon Press, 1987), p.14.
}

fugitive West Indian slave when he delineates her curling, "somewhat coarse hair," "rolling black eyes," and lips "as full as those of a hot-blooded Maroon" (p. 86). Even the nonconforming half-Swiss, half- English Frances Henri whom Crimsworth weds showcases a prospective on compliance against male supremacy which the novel facts as "black." Frances tells Crimsworth, with "a strange kind of spirit," that if her husband were an autocrat, wedding would be slavery and that "against slavery all right thinkers revolt" (p. 255). This stature is even more unambiguous when Frances tells Hunsden, who is toning intelligence with her in asquabble about Switzerland, that if he weds a Swiss wife and then defames her indigenous country, his wife will come up one night and choke him "even as your own Shakespeare's Othello smothered Desdemona" (p. 242).

In the two breathing chapters of Bronte's last and uncompleted novel Emma (1853), race relations play really a significant role: the heroine's unexpectedly noticeable blackness conveys the idea of her social incarceration due to her age, gender and social class. The two chapters are positioned in a boarding school and the spotlight is on a modest girl called Matilda Fitzgibbon, who appears at first to be an heiress, but whose father ceases to be after saying goodbye to her at the school and cannot be positioned to disburse her cost at the conclusion of the first term. Matilda is publicized, at the conclusion of the second chapter, to be of a race, or at least a physical exterior, which furnishes her vulnerable to the subsequent affront: " 'If we were only in the good old times,' said Mr Ellin, 'where we ought to be - you might just send Miss Matilda out to the Plantations in Virginia - sell her for what she's worth and pay yourself.' "6 This disclosure has been arranged for by numerous preceding passages. The narrator has informed us that Matilda has a physical exterior which makes her insufficient as a wellheeled "show-pupil," a physiognomy which repels the head mistress and causes her a "gradually increasing peculiarity of feeling" (p. 312), and "such a face as fortunately had not its parallel on the premises" (p. 313). Bronte has also specified Matilda with the name called "Fitz/gibbon," this name becomes a racist soubriquet when we recognized that it

${ }^{6}$ Charlotte Bronte, Emma, appended to The Professor, ed. Smith and Rosengarten, pp. 322-323. Ellin's "joke" becomes even less amusing when we recall that Miss Wilcox would have been pre- vented from selling Matilda as a slave not because black slavery no longer existed in Virginia but simply because England had abolished the slave trade in 1808. For an account of the abolition and emancipation movements in England, see Michael Craton, Sinews of 
begets from the nineteenth-century scientific/racist humdrum that blacks were little on the dimension of being, nearer to apes than to white Europeans: Matilda's agnomen brands her the unlawful progeny of an ape. Yet in a sagacity Matilda becomes black only at the moment in Emma at which she loses her societal position: only then do any of those around her construct overt allusions to her race or skin colouring, and then only does the reader become conscious of what it is that is "repulsive" in her "physiognomy." In Emma, Bronte may have been preparing to write down a novel which would formulate unembellished Jane Eyre's perception that she is a stranger whom Mrs. Reed could not perhaps akin to, that Mrs. Reed sees her as "an interloper, not of her race." ${ }^{7}$ Bronte uses allusions to colonized races to signify variety of social positioning in British society: female subjugation in sexual affairs, female rebellion and fury against male power, and the domineering class position of the female without family ties and a middle-class income. She does so with a combination of both compassion for the subjugated and commonplace racism: Matilda's patronymic is a racial smear, yet the condition which instigates Mr. Ellin's ruthless racism also evokes the reader's compassion for Matilda. Lucy Snowe's power of character is one of her most venerable qualities and yet to signify it Bronte perambulates the Eurocentric thought of colonized savages. The metaphorical use of race relations in Bronte's fiction portrays a disagreement between compassion for the subjugated and racism, one that becomes most perceptible in Jane Eyre (1847). The metaphorical use of race is so imperative to Jane Eyre that, much as it begins to be in Emma, the stature is enacted on the height of character. In demonstrating areal Jamaican black woman, Bronte locates herself challenging the non-figurative veracity of British race relations. Bronte's metaphorical utilization of blackness in part arises from the history of British colonialism: the occupation of racial "otherness" in Jane Eyre is to denote a comprehensive repression. But Bronte makes class and gender repression the unconcealed connotation of racial "otherness," advocating the historical reasons why colonized races would recommend cruelty, at some echelon of realization, to nineteenth-century British readers. What begins then as an embedded assessment of British command and classification with the subjugated collapses into simply an occupation of the metaphor of

Empire: A Short History of British Slavery (Garden City, New York: Anchor Books, 1974), pp. 239-284

${ }^{7}$ Charlotte Bronte, Jane Eyre (1847; rpt. New York: Penguin Books, 1984), p. 48. "slavery." But the novel's conclusion fails, in appealing customs, to screen out completely the history of British colonial domination. This multifaceted metaphorical employ of race navigates much of the complicatedness of making out the politics of Jane Eyre. In a significant interpretation of the importance of colonialism in Jane Eyre, Spivak opines that "the unquestioned ideology of imperialist axiomatics" appraises the narrative of Bronte by enabling the idiosyncratic social growth of the character Jane which has been distinguished by "U.S. mainstream feminists." Her appraisal chronicles Bertha as a "white Jamaican Creole" who can on the other hand be seen in Jane Eyre as a "native subject,"' undeterminably positioned between human and animal and subsequently debarred from the idiosyncratic humanity which Jane Eyre's feminism claims for Jane. ${ }^{8}$ While we have the same opinion with Spivak's vast evaluation of a distinctive sprain of feminism, we discover her interpretation challenging in its investigation of the mechanism of imperialist principles and its relation to feminism. Bertha is described by Spivak as a white female and a colonized "native," as what she terms, a "native 'subject."' She is therefore capable to delegate Bertha as either native or white in order to criticize both Jane Eyre and Wide Sargasso Sea as demonstration of exclusive feminist individualism. Jane Eyre provides Jane eccentricity at the cost of the "native" Bertha; Wide Sargasso Sea, on the other hand, retells the tale of Jane Eyre from Bertha's standpoint and thus simply "rewrites a canonical English text within the European novelistic tradition in the interest of the white Creole rather than the native" (p. 253). In the welfare of Spivak's assessment Bertha is either indigenous or not indigenous. Thus it is quite obvious a fact that Spivak showcases feminism to be unavoidably glued with

8

Gayatri Chakravorty Spivak, "Three Women's Texts and a Critique of Imperialism," Critical Inquiry 12 (1985), 243- 261. Two other critics have made brief allusions to the significance of race in Jane Eyre. In "Rochester as Slave: An Allusion in Jane Eyre," Notes and Queries, 31 (March 1984), R. J. Dingley notes that Rochester uses the phrase "a man and a brother" in speaking to Jane (p. 66). Dingley interprets the phrase as Rochester's impulsively premature declaration that the intensity of his passion makes him Jane's "slave." Patricia Beer frames the chapter on Charlotte Bronte in her Reader, I Married Him: A Study of the Women Characters of Jane Austen, Charlotte Bronte, Elizabeth Gaskell and George Eliot (New York: Barnes and Noble, 1974), by suggesting that the novel draws an analogy between women and slaves and noting that Bronte, unlike Jane Austen, made "serious ... comment" on this form of the "slave trade" (p. 84), but she goes no further in exploring the analogy. 
imperialism. Our own suggestion is that the historical agreement between the principles of male supremacy and the principles of colonial supremacy which informs the descriptions of so many texts of the European colonial era in fact resulted in a very dissimilar relation between imperialism and the embryonic confrontation of nineteenthcentury British women to the gender pecking order. Jane Eyre was written in reply to the similar ideological milieu which led Anthony Trollope, in his short story "Miss Sarah Jack of Spanish Town, Jamaica," to illustrate the betrothed of a post-emancipation West Indian planter with this reverberating correspondence: "Poor Maurice had often been nearly broken-hearted in his endeavours to manage his freed black labourers, but even that was easier than managing such as Marian Leslie." Bronte in Jane Eyre answers to the ostensibly avoidable equivalence in nineteenth-century British texts that compares white women with blacks in order to demean both groups and emphasize the requirement for white male rule. Bronte makes use of the analogy in Jane Eyre for her own purposes, to denote not collective lowliness but collective subjugation. This metaphorical stratagem induces some commiseration with blacks as those who are also subjugated, but does not disqualify racism. Jane Eyre yet while for the most part suppresses the derogatory history of slavery and bigoted subjugation, its conclusion betrays a fretfulness that colonialism and the repression of the voices of other races compose a "stain" upon English history and that the novel's individual requisition of the racial "other" for metaphorical ends carries with it a worrying semblance to that history. Therefore while the viewpoint Jane Eyre ultimately takes toward imperialism is Eurocentric and conformist, we come across in Jane Eyre not Spivak's "unquestioned ideology" of imperialism, but a principle of imperialism which is quarried - and then re-established in appealing and enlightening customs. An understanding of the implication of the British Empire in Jane Eyre must commence by constructing sense of Bertha Mason Rochester, the crazy, drunken West Indian wife whom Rochester keeps locked up on the third floor of his inherited manor. Bertha functions in Jane Eyre as the fundamental focal point of Bronte's consternation about cruelty, worries that encourage the plot and compel it to its wrapping up. The conclusion then harvests these worries partially by deleting the character that seems to exemplify them. Bertha only comes into this

${ }^{9}$ Anthony Trollope, "Miss Sarah Jack of Spanish Town, Jamaica," in his Tourists and Colonials, ed. Betty Jane Slemp Breyer (Fort Worth, Texas: Texas Christian University Press, 1981), p. 8. novel after about a third of its accomplishment has taken place. As she becomes visible, worries which have been situated somewhere else, conspicuously in the character of Jane herself, become engrossed and federalized in the stature of Bertha, thus paving the way for her ultimate obliteration. We read Bertha's anomalous haziness of race a haziness which is manifested inside the text itself, rather than one which requires to be mapped onto it - as unswervingly inter connected to her role as a spokesperson of dangers which intimidate the topography of Jane Eyre. She is the heiress to a West Indian fortune, the offspring of a father who is a West Indian planter and trader, and the sister of the yellow-skinned hitherto communally white Mr. Mason. She is also a lady whom the younger son of an upper-class British kin would deem wedding, and so she is unmistakably fantasized as white - or as fleeting as white — in the novel's backward-looking narrative. The critics of Jane Eyre have time and again whispered that Bertha is a white lady, basing the hypothesis on this fraction of the storyline, even though Bertha has often been sketched as a "swarthy" or "dark" white lady. But when she essentially emerges in the route of the action, the narrative links her with blacks, predominantly with the black Jamaican antislavery rebels, the Maroons. In the appearance in which she becomes noticeable in Jane Eyre, Bertha has become black as she is constructed by the sequence of events, much like Matilda Fitzgibbon becomes black in Emma. Yet in Rochester's version of the time before their wedding ceremony, when Bertha Mason was "a fine woman, in the style of Blanche Ingram: tall, dark, and majestic," there are clues, as there are in the early images of Matilda Fitzgibbon, of the uncertainty of her race. Instantaneously after Rochester delineates Bertha as "tall, dark, and majestic," he continues: "her family wished to secure me because I was of a good race" (p. 322). In the milieu of a colony where blacks surplus whites by twelve to one, where it was a custom and time-honoured exercise for white planters to compel female slaves to develop into their "concubines," and where whites were subsequently worriedly conscious of the huge population of mulattoes, Rochester's slogan accrues importance beyond its instantaneous orientation to his old family name. In this framework the slogan suggests that Bertha herself may not be of as "good" a race as he." Bertha is the offspring, as Richard Mason incongruously and it seems that gratuitously declares in his official testimony to her wedding with Rochester, "of Jonas Mason, merchant, and of Antoinetta Mason, his wife, a Creole" (p. 318).The haziness of Bertha's race is noticed by this labelling of her mother as a "Creole." The word "creole" 
was used in the nineteenth century to consign to both blacks and whites born in the West Indies, a custom which caused some bewilderment: for example, in its description of the word the $O E D$ cites a nineteenth-century history of the U.S. in which the writer writes:

"There are creole whites, creole negroes, creole horses, \&c.; and creole whites, are, of all persons, the most anxious to be deemed of pure white blood."

When Rochester exclaims of Bertha that "she came of a mad family; idiots and maniacs through three generations! Her mother, the Creole, was both a madwoman and a drunkard!" he posits both insanity and inebriation in his spouse's maternal line, which is again vigorously and obscurely, pigeonholed "Creole." By doing so, he links that line with two of the most familiar stereotypes connected to blacks in the nineteenth century. As Bertha comes out as a character in Jane Eyre, her blackness is made more unambiguous, regardless of Rochester's desire to persuade Jane, and possibly momentarily himself, that "the swelled black face" and "exaggerated stature" of the lady she has seen are "figments of imagination, results of nightmare" (p. 313). But when Jane starts detailing to Rochester the face she has seen reflected in the emulate, the topoi of racial "otherness" are very palpable:

"Fearful and ghastly to me - oh sir, I never saw a face like it! It was a discoloured face - it was a savage face. I wish I could forget the roll of the red eyes and the fearful blackened inflation of the lineaments!" "Ghosts are usually pale, Jane." "This, sir, was purple: the lips were swelled and dark; the brows furrowed: the black eyebrows widely raised over bloodshot eyes." (p.311).

The importance on Bertha's colouring in this passage - she is ardently not "pale" but "discoloured," "purple," "blackened" — the indication to rolling eyes and to "swelled," "dark" lips all tenaciously and stereotypically blotch Bertha as non-white. Jane's use of the word "savage" suggests the insinuation of her explanation of Bertha's characteristics, and the rosiness which she sees in Bertha's rolling eyes suggests the inebriation which, triumphing the familiar racist principle, Bronte has allied with blacks since her early days. As Bertha's "lurid visage flame[s] over Jane" while she slanders in bed, causing her to mislay awareness, the vaguely dark blood Bertha has inherited from her maternal queue becomes completelyobvious in a method that recollects a passage from Bronte's African juvenilia. In this passage in her Roe Head Journal the radical Quashia has achieved a victory in a mutiny against the white British colonists, and having occupied the citadel built by the colonists, celebrates tipsily, in emblematic contravention, on the "silken couch" of the white queen. Muchlike the mutinous Quashia, the Jamaican Bertha-become-black is the novel's embodiment of the craving for vengeance on the fraction of the colonized races, and Bronte's fiction observes that such a craving for vengeance is not unjustifiable. The alliance of Bertha with blaze recalls Jane's former enquiry to herself: "What crime was this, that lived incarnate in this sequestered mansion, and could neither be expelled nor subdued by the owner? - what mystery, that broke out, now in fire and now in blood, at the deadest hours of the night?" (p. 239). The tongue of this passage powerfully invokes that used to illustrate slave rebellion in the British West Indies, where slaves used fires both to devastate belongings and to signal to each other that a rebellion has started vigorously. White colonists gave rebuttal to slave insurgency with great disquiet, like that articulated by one author for Blackwood's in October 1823, in reply to the reports of the Demerara slave revolt: "Give them [the abolitionists] an opportunity of making a few grand flowery speeches about liberty, and they will read, without one shudder, the narrative of a whole colony bathed in blood and fire, over their chocolate the next morning."

In 1846 Bronte completed writing Jane Eyre, eight years after the complete liberation of the British West Indian slaves in 1838. But this is also to keep in our mind that the novel itself is unquestionably set prior to liberation. As Q. D. Leavis observes that it may not be probable to identify the finishing moment of Jane Eyre further than within an array of twenty-seven years, between 1819 and 1846. At the end of her autobiography when Jane says, "I have now been married ten years," the date is at the latest 1846 when Bronte completed writing Jane Eyre; thus Jane's wedding ceremony with Rochester most likely occurs in 1836 at the latest. The year prior to their wedding, Jane is told by Rochester that he has incarcerated Bertha for ten years in his third-story room ("she has now for ten years made [it] a wild beast's den - a goblin's cell," as he puts it [p. 336]). At the newest, then, Rochester primarily locked Bertha in that room in 1825, and in view of the fact that he lived with her prior to that for four years, they were probably married in 1821 . Bronte without a doubt supposed to put down the exact date of the novel indefinite - she pinpoints the year of Rochester's and 
Bertha's nuptials with a dash in Richard Mason's testimony to their wedding - but it is comprehensible that even at the upto-the-minute probable dates, proceedings in the novel take place well prior to liberation, which was acknowledged in 1834 but only satisfied in 1838. Bronte may have supposed for the proceedings of Jane Eyre to take place in the 1820s and '30s, as we have recommended above, during the years in which, due to the financial demur of the British sugar colonies in the West Indies, planters for cede scalating destitution on the slaves and gradually more feared their upheaval. When Bertha runs away from her ten years' incarceration to endeavour at regular intervals to stab and bum her sadistic oppressors, and as Rochester says, to dangle her "black and scarlet visage over the nest of my dove" (p. 337), she is figuratively enacting specifically the genus of insurgency feared by the British colonists in Jamaica. But what is the exact logic behind Bronte's writing of a novel symptomatic of the risk of a slave revolution in 1846, after the liberation of the British (though not the U.S. or French) slaves had by now taken place? Undeniably, in 1846 it was obvious that the English West Indian colonies were deteriorating hastily, and the focal point of British colonial concentration was shifting to India. Whereas the novel's precise detailing of colonialism is on the whole blatantly metaphorical, nevertheless it in division engages colonialism on a nonrepresentational echelon. Bertha's story, on the other hand at length insensitive to her as a human being, nevertheless does accuse British colonialism in the West Indies and the "stained" riches that came from its domineering decree. When Jane amazes "what crime ... live[s] incarnate" in Rochester's well-appointed manor "which [can] neither be expelled nor subdued by the owner" (p. 239), Jane Eyre observes that the black-visaged Bertha, locked up out of vista in a well-appointed English manor, does without a doubt "incarnate" a historical misdemeanour. As Rochester himself defines Thorn field as a "tent of Achan" (p. 328), alluding to Joshua 7, in which Achan takes loot unjustifiably from another people and conceals it under his marquee, thus bringing down an imprecation upon all the kids of Israel. The third floor of the house, where Bertha is locked up, Jane thinks, is "a shrine of memory" to which "furniture once appropriated to the lower apartments had from time to time been removed ... as fashions changed" (p. 137). The figuratively booming language Bronte uses as Jane travels round the house gives the impression that Thornfield, and predominantly its third floor, celebrates the history of the British ruling class as franchised by the Rochesters, whom Mrs. Fairfax, acting concurrently as family historian and guide to the house - that is, guide to the "house" of Rochester in both wits - acknowledges to have been "rather a violent than a quiet race in their time." The ambience of the third floor of this "house" is profound with the introverted history of offences committed by a "violent race," misdemeanours which have been disconnected from vista as fashions distorted. History keeps flaring up into the language of this passage, as it does a little sentences afterwards when Jane, mountaineering out onto the top of the hall, finds herself on a echelon with the black gregarious Eurasian crows who reside there, just above Bertha's head, and who are here referred to, with an uncanny - and racist reverberation, as "the crow colony" (p. 137). Jane's reactions to this place crowded with history - she is fascinated but "by no means covet[s] a night's repose on one of those wide and heavy beds" (p. 137) - suggests her attentiveness of the tyrannical ambience of colonial history and her awkwardness lest she, by lying in the divan of the Rochester's, should get trapped up in it. Bronte's account of the room where Bertha has been incarcerated for ten years - without a casement, with only one light hung from a figurative chain - also obstinately rejuvenates her consciousness that the blackvisaged Bertha, much like Quashia Quamina, has sufficient grounds to take vengeance on a "violent race." In these moments in Jane Eyre Bronte delicately advocates that the history incarcerated in the British "shrine of memory" is one of "crime incarnate" in Bertha. But the "slavery" which Bertha's colouring and incarceration indicate has a more calculatedmetaphoricalpurpose. The abundantanalogues that Bronte draws between Bertha and other characters in Jane Eyre recommend that her most imperative narrative function is to exemplify these analogues, to give them a glowing and tangible outline. The "slave" mutiny that Bertha's gloomy hostility calls to mind also have a metaphorical connotation. As in her juvenilia and, less outstandingly, in her other foremost novels, Bronte makes use of slavery in Jane Eyre as a stature for financial coercion, a stature that the company of Bertha embellishes and makes unembroidered. Among recent critics who have defined affairs of social class as innermost to the politics of Jane Eyre, Terry Eagleton has found Jane Eyre the most conventional. He has seen in Jane Eyre, as in all Bronte's novels, a fight between idiosyncratic bourgeois principles and old-fashioned upper-class principles. Eagleton has read Bronte's novels as "myths" that labour toward assessing these standards, in part through traditional conclusions in which the protagonists "negotiate passionate self-fulfilment on terms which preserve the social and moral conventions intact" by taking postures within the social 
structure that has subjugated them earlier in the novel. ${ }^{10}$ Both Igor Webb and Carol Ohmann have seen a more far-reaching plunge in Jane Eyre, in fraction because they both chew over issues of gender to be as central to the novel as issues of class. ${ }^{11}$ Ohmann argues that Bronte is concerned with gender and class "deprivation" in Jane Eyre, and that, wedged between her conservatism and her radicalism; she affords a solution only on a personal echelon. But, Ohmann pens down, "in the very rendering of Jane Eyre's longing for fulfilment, Bronte conveys a moral imperative with broadly social implications," even though the novel does not track these out (p. 762). Webb has seen Jane as the haulier of a "revolutionary individualism" through whom the novel wrestles against disparity of gender and class. He too has seen Jane Eyre as capable of achieving radical egalitarianism only on a personal echelon: "the full transformation of society seems daunting, and the novel retreats into its overgrown paradise. This paradise serves at once as a criticism of that other, public world and as an announcement of the deep dispiriting gulf between active self-fulfillment and social possibility" (p. 86). With Ohmann and Webb, we have found a more deep-seated urge in Jane Eyre than does Eagleton, and we have the same opinion with their stress upon the novel's two folded fight against class and gender discrimination. Yet we have found Bronte's resistance to class discrimination both more societal and more inadequate than Ohmann and Webb have done. Jane Eyre does necessitate a broader redeployment of riches, but it also confines the beneficiaries of these lately equalized possessions to a particularassemblage, the lower-middle class. Jane Eyre's situation on monetaryre deployment is penned down through the essential metaphorical rudiments of ethnic "otheress," colonialism, and enslavement. As in her premature African tales, Bronte does not make use of enslavement as equivalence for the assortment of the working class but for that of the lower-middle class, for those who are strained into "governessing slavery" as Rochester pens down effectively (p. 298). Jane's governessing at Thornfield becomes like enslavement to her only when Rochester does arrive with his superior ruling-class associates and she encounters the barbarizing stare of her

${ }^{10}$ Terry Eagleton, Myths of Power: A Marxist Study of the Brontes (New York: Barnes and Noble, 1975), pp. 4, 16.

${ }^{11}$ Carol Ohmann, "Historical Reality and 'Divine Appointment' in Charlotte Bronte's Fiction," Signs 2 (1977), pp. 757-778 and Igor Webb, From Custom to Capital: The English Novel and the Industrial Revolution (Ithaca: Cornell University Press, 1981), esp. pp. 70-86. class superiors. Prior to this, those around Jane celebrate her as a social equivalent. Mrs. Fairfax does help Jane to take away her boater and shawl when she first appears, and Adele is too babyish and also of too doubtful an origin to care for her governess with pre-eminence. Bronte exclusively assembles the ambience between the three of them - though appreciably not between the three of them and the servants - as a utopian run away from a world conquered by class hierarchy. Mrs. Fairfax conspicuously grades the segregation of the working class from this classless utopia when she informs Jane, just after displaying her enchantment that Jane has approached to be her "companion": "you know in winter times one feels dreary quite alone, in the best quarters. I say alone - Leah is a nice girl to be sure, and John and his wife are very decent people; but then you see they are only servants, and one can't converse withthem on terms of equality; one must keep them at a due distance for fear of losing one's authority" (p. 128). Some responsiveness of the expenditures even of having a class lower than one's own, a crisis with which Jane Eyre is in common very little worried, comes through in this route. For the most part, on the other hand, Jane Eyre pays negligibleconcentration to the working class. As an alternative it sketches analogues between enslavement and Jane's social situation as one of the subaltern lower-middle class. Both Jane and the narrator put forward these comparisons, not in reply to the vocation Jane has to carry out but in reply to the embarrassing attitudes of her class superiors. In her initial stage when she first dissolves into John Reed, she cries out: "You are like a murderer - you are like a slave-driver - you are like the Roman emperors!" and the adult Jane explains to the reader, "I had drawn parallels in silence, which I never thought thus to have declared aloud" (p. 43). Jane as narrator not only welcomes the child's rhetorical expression but makes it into a more vigorous symbol when she resumes, "I was conscious that a moment's mutiny had already rendered me liable to strange penalties, and, like any other rebel slave, I felt resolved, in my desperation, to go all lengths" (p. 44). Afterwards, when Jane has been positioned by Brocklehurst on the chair, she thinks of herself as "a slave or victim" (p. 99). Jane Eyre itself ties a parallel between enslavement and Jane's social situation as a child through the character Bertha. Jane's hurried angry outburst of vehemence against her handling at Gateshead takes place in her tenth year there: Mrs. Reed grumbles to the adult Jane, "to this day I find it impossible to understand: how for nine years you could be patient and quiescent under any treatment, and in the tenth break out all fire and violence" (p. 267). Jane escorts herself 
to "mutiny" and becomes a "rebel slave" in her tenth year, like Bertha who after ten years in her third floor room "br[eaks] out, now in fire and now in blood" (p. 239). The descriptions of social class enslavement happen again in Jane's later life in the milieu of her wakefulness of the financial disparity between her and Rochester. She remarks after their rendezvous that the reception of his precious offerings makes her feel like a besmirched slave, and when he swanks that he will envelop her head with aninvaluable shroud, she complains that if he does she will sense "like an ape in a harlequin's jacket" (p. 288). Given the bigoted nineteenth-century alliance of blacks with apes, the phantom of Bertha's black phizog under the embellished shroud incarnates Jane's clarifications. This vital passage, in which Jane's brief look at Bertha's black face under the bridal shroud, bounced back in her personal mirror, and then sees Bertha scratch the shroud in half, incorporate the other appearance of enslavement that Bertha both incorporates for Jane and then enables her to keep away from. Quite a few feminist critics have commented on this passage, elucidating Bertha as either the proxy or the double who demonstrates Jane's wrath against the manacles of gender. Sandra Gilbert and Susan Gubar predominantly intricate on this prototype in Jane Eyre, unfolding Bertha as Jane's "dark double," the wild, animal-like quintessence of Jane's blazing annoyance. ${ }^{12}$ What we would adjoin is an importance on the dimness of the binary, on the technique in which, by fabricating the "savage" Jamaican Bertha as Jane's "dark double," Bronte strategically transcribes the poignant vigour of the facts of enslavement and of volatile race relations following liberation in the colonies to stand for the strains of the gender pecking order in England. The descriptions of bondage are both all-encompassing and intimately attached to colonial principles. When Rochester tells Jane, as he gives an account of the story of his life, "hiring a mistress is the next worse thing to buying a slave: both are often by nature, and always by position, inferior: and to live familiarly with inferiors is degrading" (p. 339), his words take on an astonishing reverberation in the milieu of the story he has just told. Rochester obtained a West Indian kismet by wedding a Jamaican wife and consequently stayed in Jamaica for four years. A well-to-do white man living in Jamaica prior to liberation would unquestionably have had slaves to hang around him, and his Jamaican kismet would

${ }^{12}$ See Patricia Meyer Spacks, The Female Imaginaton (New York: Knopf, 1972), pp. 64-65; Rich, pp. 97-99; and Gilbert and Gubar, pp. 336-371, esp. 359-362. undoubtedly have been the artefact of slave labour, so when Rochester discusses what it is similar to purchase and be alive with slaves he knows what he is addressing. When he juxtaposes his associations with women to keeping slaves, then, the analogue is given an appalling luminosity by his own narration as a slave master. Rochester pens down brilliantly this parallel following the reader, with Jane, has seen his wife's "black and scarlet" phizogbudding from her penal complex, an occasion that makes understandable that it is not only Rochester's mistresses who are his "slaves." When Jane takes caution then from Rochester's correspondence, Bronte proposes that Jane is acknowledging more than that she would not be shrewd to become Rochester's aficionado without lawful approval. Jane Eyre acquaintances black people with repression by portraying parallels between the black slaves, in meticulous amount, and those browbeaten by the hierarchical social class, power structure and gender in Britain. So far the narrative purpose of the black-visaged Bertha and of Jane Eyre's references to colonialism and bondage has a convinced reliability to history, even though as the alliance between blacks and apes postulates, these analogies are not liberated from racism. In accumulation, this employment of the slave as a metaphor focalizes our concentration not so much on the subjugation of blacks as on the condition of subjugated whites in Britain. Nevertheless, the analogies at least unreservedly concede the repressive condition of the non-white races subjected to the British Empire. But incongruously, the allusions to dark skin and to empire take place in particular the conflicting background in Jane Eyre as well, most conspicuously in the descriptions of Blanche Ingram. The conceited Blanche, with her "dark and imperious" eye (p. 214), whose manners makes Jane so excruciatingly conscious of her own social lowliness, appears primarily to demonstrate class oppression. Hitherto when Mrs. Fairfax does describe Blanche to Jane, she accentuates her darkness: "she was dressed in pure white," Mrs. Fairfax transcribes, she had an "olive complexion, dark and clear," "hair raven-black ... and in front the longest, the glossiest curls I ever saw" (p. 189). When Jane first glances at Blanche, she too highlights her darkness - "Miss Ingram was dark as a Spaniard," Jane comments - totalling that Blanche has the "low brow" which, similar to dark skin, was a blotch of racial lowliness according to nineteenth-century race-science. Rochester unswervingly acquaintances Blanche with Africa: he might be interpolating of Bertha when he tells Jane, with superfluous viciousness, that his apparent fiancée is "a real strapper ... big, brown, and buxom; with hair just such as the ladies of Carthage must have had" (p. 
248). These allusions to Blanche's darkness, and to her other similarities to "inferior," dark races, only make wisdom in the background of the anomalous idiom, "dark and imperious." The employment of the word "imperious" to illustrate Blanche's ruling-class intelligence of dominance/superiority calls to mind the connection between the British and their black-skinned imperial subjects. In that apparatus, it was not the dark people who were "imperious," that is, in the situation of arrogant imperial authority, but the British themselves. By equating the virtues of darkness and autocracy in Blanche, Bronte observes that imperialism unwraps both these unwanted merits in Europeans - that the British have been tainted, "darkened," and made "imperious" or domineering by contact with the racial "other," and that such alliance makes them haughty oppressors both overseas, and, like Blanche, at home in England. The white clothing of Blanche, her mother's pet name for her ("my lily-flower," p. 207), and the denotation of her name all highlight the sardonic inappropriateness between what she tries to be and what she is: rather than incorporating model white European womanliness, this titled Englishwoman is tarnished by the infectious darkness and oppressiveness of British colonialism. The alliance of the class tormenter with "dark races" is hinted at in the images of the Reeds as well as the Ingrams. John Reed criticizes his mom for "her dark skin, similar to his own" (p. 47), and Jane compared John to a Roman ruler. John grows into a young man with "such thick lips" (p. 122), while Mrs. Reed's phizog in her last sickness becomes, like Bertha's, "disfigured and discoloured" (p. 270). Lady Ingram, who ridicules governesses in front of Jane, and who within Jane's enquiry announces that she has seen in Jane's physiognomy "all the faults of her class" (p. 206) also has characteristics like Bertha's: her countenance is "inflated and darkened" — with pride (p. 201). Like John Reed, Lady Ingram has "Roman features," and she too is connected with the British Empire. She has, Jane says, "a shawl turban of some gold-wrought Indian fabric [which] invested her (I suppose she thought) with a truly imperial dignity" (p. 201). Jane Eyre poignantly draws unappealing parallels between the British Empire, brought to mind by Lady Ingram's Indian shawl, and the Roman Empire, whose rulers, the young Jane has articulated, are killers and slave drivers. Both the class oppressiveness of these well-to-do Britons and their dark characteristics take place, in the novel's emblematic structure, from their relationship with Empire. With this peculiar twirl, racial "otherness" becomes as well the signifier of the tormenter. By using black-skinned people to denote not only the subjugated but also the tormenter, Bronte spectacularly clears the signifier of black skin in her novel of any of its connotation in historical veracity and makes it simply communicative of "otherness." By transmitting these two conflicting meanings to the signifier "non-white," Jane Eyre follows this common sense: repression in any of its exhibition is "other" to the English world of the novel, thus ethnic "otherness" signifies repression. This ison the whole essentially deceitful move in the novel's metaphorical stratagem, the one that discloses the furthermost apathy to the humanity of those subject to British colonialism. The passage that correlates English tyrants with "dark races" is the most elusive about British involvement in enslavement and empire. Jane Eyre's anti-colonial political principles, it becomes comprehensible, are middle-of-the-road. The resistance to colonialism arises not out of anxiety for the welfare of the "dark races" subject to British colonization nonetheless the African slaves in the West Indian colonies, the Indians whose financial system was being shattered under British statute - but first and foremost out of anxiety for the British who were, as the novel's metaphorical configuration represents it, being spoiled by their contact with the built-in absolutism and oppressiveness of black-skinned people. Jane Eyre also acquaintances the gender persecutor with darkness, principally all the way through Rochester. Rochester's darkness and the symbolic reason for it emerge in the central charade passage. The first two scenes Rochester ratifies are delicately camouflaged episodes from his own life. In the first, which ratifies the word "bride," Rochester marries a tall, "strapping," blacklady. The second scene validates the word "well" by demonstrating the get-together of Eliezer with his future bride, whom, as is the case with Rochester, Eliezer has been administered to get married by his father. The final scene, validating the word "Bridewell," both propounds the incarceration attendant upon making such a marriage ceremony and symbolically represents the repercussions of Rochester's contact with black-skinned people in search of fortune. In this scene Rochester is himself shackled like a slave and his phizog is "begrimed" by a gloominess that has canopied him. That his association with the colonies is the foundation of his circumstances is recommended both by the previous scenes and by the depiction of his coat which looks "as if it had been almost torn from his back in a scuffle" (p. 213) akin to the one he has with Bertha not long afterward. Rochester's gloominess is intensified when his "begriming" past is alluded to and when he argues the probable domineering command of his situation in the gender hierarchy. During the epoch of Rochester's and Jane's fiançailles, Bronte goes on to use the 
descriptions of enslavement to symbolize Jane's less important command in the relationship. But she swerves from building an unswerving parallel with the British enslavement of Africans by aligning Rochester's commanding phallocentric authority over Jane with that not of a British but of an Eastern slave master. This fraction of Jane Eyre is moneyed with descriptions of Turkish and Persian authoritarians, sultans who prize their much-loved slaves with trinkets, Indian wives forcefully bound to expire in horrendous "suttee," and women imprisoned in Eastern seraglio. The actuality of British involvement in slavery vigorously arises at one point in this fraction of the storyline - Rochester facsimiles the emancipationists' catchphrase when he articulates Jane that she is too self-possessed with "a man and a brother" (p. 169) - but Jane Eyre unremittingly displaces the culpability for enslavement onto the "dark races" themselves, only referring to slavery unswervingly as an exercise of black-skinned people. At some point, for instance, Jane Eyre uses brawny and appalling descriptions of slavery to portray the peripheralized position of wives, but regardless of references to such ingredients of British slavery as slave markets, manacles, and insubordination, the set-up invoked perambulate not British colonial command but the tyrannical, domineering habits of non-whites. As Rochester has just compared himself to "the Grand Turk," proclaiming that he favours his "one little English girl" to the Turk's "whole seraglio" (p. 297), to which Jane responds with courage:

"I'll not stand you an inch in the stead of a seraglio. ... If you have a fancy for anything in that line, away with you, sir, to the bazaars of Stanboul, without delay, and lay out in extensive slave-purchases some of that spare cash you seem so at a loss to spend satisfactorily here." "And what will you do, Janet, while I am bargaining for so many tons of flesh and such an assortment of black eyes?" "I'll be preparing myself to go out as a missionary to preach liberty to them that are enslaved - your harem inmates amongst the rest.... I'll stir up mutiny; and you, three-tailed bashaw as you are, sir, shall in a trice find yourself fettered amongst our hands: nor will I, for one, cut your bonds till you have signed a charter, the most liberal that despot ever yet conferred.” (Pp.297-298).

\section{CONCLUSION}

By bracketing Rochester's situation at the pinnacle of the domineering gender pecking order, like Jane's situation at the underneath, with black-skinned peoples, Jane Eyre suppresses the narration of British colonial domination and, in meticulous detailing, British enslavement of Africans, by smudging all strands of domination "other" - non-British, non-white, the consequence of a tarnishing contact with "dark races." Even when Rochester unswervingly proclaims his authority over Jane, exclaiming of "attach[ing her] to a chain" (p. 299), Jane Eyre collages him with a sultan, in spite of to a white-skinned British slave master. All strands of cruelty in this middle-of-the-road curl in the novel's metaphorical stratagem become something the British are in risk of being besmirched by, something alien and "other" to them. In antagonism to this peril - the danger of becoming "begrimed" by the coercion which the novel acquaintances with the black-skinned - Bronte constitutes a substitute unswervingly out of middle-class domestic principles: maintaining a dirt-free house. Hygienic and unhygienic, healthy and detrimental environments form a fundamental figurative configuration in Jane Eyre. In Shirley, Caroline's sickness is foreseen by a passage about the entrance of "the yellow taint of pestilence, covering white Western isles with the poisoned exhalations of the East, dimming the lattices of English homes with the breath of Indian plague" (p. 421). In the same way, in Jane Eyre Bronte again and again acqua instances detrimental, infectious environments with racial "otherness" and with subjugation, that "poisoned exhalation of the East." When Rochester determines to leave Jamaica where he has occupied a black wife as a "slave," participated in slavery, and become "blackened," Jane Eyre poses the hostility between repressive Jamaica and unadulterated England in terms of ambience. As Rochester recounts it:

"it was a fiery West Indian night; one of the description that frequently precede the hurricanes of those climates. Being unable to sleep in bed, I got up and opened the window. The air was like sulphur streams - I could find no refreshment anywhere. Mosquitoes came buzzing in and hummed sullenly around the room. .... the moon was setting in the waves, broad and red, like a hot cannon-ball - she threw her last bloody glance over a world quivering with the ferment of tempest. I was physically influenced by the atmosphere.... I meant to shoot myself.... "A wind fresh from Europe 
blew over the ocean and rushed through the open casement: the storm broke, streamed, thundered, blazed, and the air grew pure. I then framed and fixed a resolution." (p.335)

Under the authority of "the sweet wind from Europe," Rochester determines to revisit England, to "be clean" in his own sight (p. 334) by going away from the locale of colonial domination. In a very analogous passage Jane acquaintances repression and liberty with healthy and detrimental environments. After she has run away from Thorn field and settled at Morton, she rebukes herself for moping: "Whether it is better," Jane asks, "to be a slave in a fool's paradise at Marseilles - fevered with delusive bliss one hour suffocated with the bitterest tears of remorse and shame the next - or to be a village schoolmistress, free and honest, in a breezy mountain nook in the healthy heart of England?" (p. 386). Jane here envisages the gender and class enslavement she would undergo as Rochester's mistress as an agitated, overpowering, and southern atmosphere. The soggy pestilential/contagious mist of Lowood School is one of the novel's most severely detrimental environments; the ambience at this orphan house where Jane thinks of herself as "a slave or victim" is the undeviating outcome of class repression. After so many pupils die of the epidemic typhus fever stimulated by the noxious surroundings, "several wealthy and benevolent individuals in the county" convert it into a less tyrannical establishment by the act of tidiness: a new construction is erected in a healthier site, and "brackish fetid water" (p. 115) is no longer used in the production of the children's food. Creating a dirt-free, hale and hearty, middle-class environment stands as Jane Eyre's figurative substitution to participation in subjugation. As Rochester is appealing in his most shrewd endeavour to guarantee him of Jane's love, by bringing home noticeable competitor, he also gives instructions that his house be cleaned. Anenormous commotion is made over eviscerating the house Jane had ingenuously considered to be already "beautifully clean and well arranged" (p. 193). But what Rochester requires to have cleaned out of his house as he is trying to achieve an Englishwoman's love is the dark-faced spouse in his top storey that represents his ruining colonial history, his "marriage" to the colonies. Regardless of all the cleaning "such scrubbing," Jane articulates, "such brushing, such washing of paint and beating of carpets, such taking down and putting up of pictures, such polishing of mirrors and lustres, such lighting of fires in bedrooms, such airing of sheets and feather-beds on hearths, I never beheld, either before or since" (p. 193) - the existence vestiges in Thornfield that makes Rochester name it "a great plaguehouse" (p. 173). All that he can carry out with the "plague" in his residence is to employ a lady to "clean" her away into anisolated locked room. And as anaide memoire of this "plague," Grace Poole intermittently becomes apparent, amidst all the tidiness/cleaning, from the third story, "damping" Jane's joyfulness and causing her "dark" hypothesis, in order, as both the most professional cleaner and as the signifier of the enormous "stain" in the residence, to provide recommendation to the other servants: "just to say a word, perhaps ... about the proper way to polish a grate, or clean a marble mantle piece, or take stains from papered walls" (p. 194). The other enormous cleaning movement in Jane Eyre takes place as Jane makes up her mind to "clean down" Moor House (p. 416), and it grades a more triumphant endeavour at percolating tyranny than the one at Thorn field. Jane cleans the residence to commemorate the egalitarian allocation of her lately acquired inheritance, which will facilitate her to breathe there gleefully with her brand newkin. Bronte pens down Jane's "equal" partition of her kismet, speechifying an insurgency against class oppression, even though figuratively it constitutes are deployment of riches in support of only a restricted assemblage of people, the lower- middle class. When St. John Rivers informs Jane that he, Diana, and Mary will be her brother and sisters without this forfeit of her "just rights," she replies, in a tenor of fervent confidence Bronte perceptibly and emphatically endorses: "Brother? Yes; at the distance of a thousand leagues! Sisters? Yes; slaving amongst strangers! I wealthy - gorged with gold I never earned and do not merit! You, penniless! Famous equality and fraternization! Close union! Intimate attachment!' "(p. 413). This type of redeployment of riches, Bronte opines, giving Jane the tongue of the French revolution - "Liberte! Egalite! Fraternite!" - will accurate the wrongs of the lower-middle class, and dirt-free from it the scratch of darkness which constitutes repression. Its women will no longer have to "slave" among aliens like blacks; its men will no longer have to wander into the farflung, hazardous milieu of the "dark races" in the colonies. With Jane, Bronte churns out the claims of "brotherhood," as her plot reshuffles riches: truthfully accredited "fraternity," Jane Eyre suggests, necessitates disseminating riches uniformly, not allowing a brother or sister stay as a penniless "slave." But to only a restricted assemblage among those who might enquire "Am I not a man and a brother?" does the novel respond "Yes." The plot of the novel works toward a redeployment of command and riches, levelling and an end 
to repression/subjugation just as Jane herself does, but its utopia remains biased; its "revolution" ameliorates only the assortment of the middle class, concluding both the working class and those from whom the stature of "slavery" has been commandeered in the earliest stage. As Jane sincerely expresses her "revolution," it is one which distinctively depends on deleting the scratch of racial "otherness." To imply her utopian end to financial unfairness, Jane constructs a dirt-free, hale and hearty environment, free of pestilence: her aim, she articulates St. John, is "to clean down (do you comprehend the full force of the expression?) to clean down Moor House from chamber to cellar" (p. 416). Jane performs factually to "set her own house in order," erecting a spotless, vigorous, egalitarian, middle-class, familial milieu as the substitution for oppression/subjugation. This milieu is not, on the other hand, to the tang of St. John, who wants to compel Jane into an in egalitarian nuptials and to take her to the detrimental environment of British India, to assist him sermonize his rather dissimilar standards of chain of command and domination to black-skinned people. Jane acknowledges this disparity in outlook and their inappropriateness when St. John fails to welcome her housecleaning: "this parlour is not his sphere," she fathoms, "the Himalayan ridge, or Caffre bush, even the plague- cursed Guinea Coast swamp, would suit him better" (p. 419). In spite of determining that it is her vocation to go into this new-fangled setting of pestilence, "dark races," and hierarchical domination, Jane feels "called" to revisit to a house which, being generously proportioned and more discoloured by repression, will be more knotty to "clean down" - Rochester's Thorn field. But by all means when she enters there she sees that this "plague-house" has already been "cleaned down." Bronte's plot takes its essential role in the similar motion as Jane - cleaning, decontaminating, and demanding to generate humankind free of tyranny. And the scheme works specifically in the stipulations of the oratory of Jane's "revolution." It redistributes riches and levels the score of gender power, and it operates so by obliterating Bertha, the discolouring dark lady who is the mouthpiece of the peripheralized/ marginalized voices who are countless, oppressed by those who belong to the centre of a power structure represented oppression. In the ending of Jane Eyre, Bronte creates the world she can envisage liberated from oppression. Jane Eyre most fervently protests against: gender repression and the financial subjugation of the lower-middle class. In the novel's utopian conclusion lies much of the world-shattering vigour that made its current readers worried: the novel enacts Bronte's impregnation of a gender and middle-class insurrection. The disfigurement of Rochester and the loss of his possessions in Thorn field redeploys power between him and the newly-propertied Jane. Jane tells her previous "master" vigorously that she is now both independent and rich: "I am," she says, "my own mistress" (p. 459). And in the last chapter Jane unambiguously defines their wedding as egalitarian, unlike most: "I hold myself supremely blest beyond what language can express; because I am my husband's life as fully as he is mine" (p. 475). The ending of Jane Eyre also relentlessly penalizes Rochester for his possession of colonial riches. Gratifying Rochester's own insinuation with the accursed riches unfairly stolen by Achan, Bronte's conclusion enacts a decontamination like that of Achan, who is "stoned with stones and burned with fire" (Joshua 7: 25) for convoying the "accursed thing" into the base camp of Israel. Unlike Achan, Rochester remains alive, but his "tent of Achan" - his well-appointed, cruel, "plague-house" - is shattered and his misbegotten riches driven out from Jane Eyre. But this insurrection against gender repression and the financial oppression of the middle class, and even this agenda of decontaminating spurious colonial riches, is made feasible by another type of domination and repression. The uprising behind Jane's rebellion is that of the black lady who figuratively represents both the subjugated and the tormenter. Bertha establishes the enormous performance of cleaning in Jane Eyre, which sweeps away Rochester's tyrannical colonial riches and disparages the supremacy of his gender, but then she herself is cleaned away by it - burned and as it were purified from the novel. Bronte constructs the racial "other" as the personified signifier of repression, and then makes this symbol, by the volatile volatility of the circumstances it incorporates, devastate it. Jane Eyre ends with a quick look of the decontaminated, more egalitarian planet fashioned by this emblematic sacrifice of the racial "other," Bronte's multifaceted working out of ethnically obtainable descriptions. But Jane Eyre does not come to an end as serenely as we might anticipate after this holocaust of the symbol of racial "otherness" and oppression. The conclusion betrays Bronte's awkwardness about her own metaphorical devices, about the technique in which her use of racial dissimilarity as a signifier necessitates a vicious muting, a deletion of the humanity of the real people inside the bodies discernible as "other." This awkwardness becomes palpable in the technique the phantom of the racial "other" vestiges to haunt the conclusion ofJane Eyre, even though desiccated into the appearance of the "insalubrious" fog which hangs around Ferndean, where Jane and Rochester reconcile after 
the "cleaning down" of Thornfield (p. 455). The soggy and noxious ambience of Ferndean interrupts the utopian rudiments of the conclusion, representing that the world of Jane Eyre still not wholly decontaminated of suppression. And the suppression which that fog must symbolize, now that it no longer refers to class or gender repression, is that unique repression which on one stage Jane Eyre has tried so solidly to relocate and suppress: the repression of a variety of black-skinned peoples by the British Empire. The ambience of Ferndean recalls the piece of information that, even if Rochester's contaminated colonial riches has been cleared away, the riches Jane is intelligent to bring him, authorizing her to convene him on equal conditions - and the riches she previously distributes in such a meticulously egalitarian and "revolutionary" fortitude - has a colonial foundation. It comes from her uncle in Madeira, who is a negotiator for a Jamaican wine producer, Bertha's brother. And the locale of Jane's uncle John in Madeira, off Morocco, on the East Africa shore, where Richard Mason stops on his way home from England, also calls to mind, through Mason's route, the triangular circuit of the British slave merchants, and advocates that John Eyre's affluence is mixed up in the slave business. The particulars of the scene in which Bronte has Jane get hold of her kismet spot Jane's monetary and literary connivance in colonialism too. St. John issues a statement about Jane's elevation to kismet by tugging the letter out of a "morocco pocket-book" (p. 404), and he is intelligent enough to recognize Jane as the heritor because she has penned down her name, on a white piece of paper, in "Indian ink" (p. 407). In this technique Jane Eyre bridges the operation of lettering with colonialism. Distinctively penning down Jane Eyre conniving one's own victorious individuality as a lady no longer subjugated by class or gender - or writing Jane Eyre, the narrative of a redeployment of riches and power between men and women - rests on a colonial "ink." Whether heedfully or not, Bronte acknowledges that reliance in the winding up of Jane Eyre. Akin to colonial mistreatment itself, bringing home the loots of other nations to become goods, such as Indian ink, the use of the racial "other" as a symbol for class and gender battles in England commodifies colonial subjects as they survive in historical genuineness and transfigures them into East or West "Indian ink," ink with which to pen down a novel about finishing repression in England. The flaring-up of the words "Indian ink" into Jane Eyre demonstrates, at some height, Bronte's awkwardness about the East Indian colonialism to which England was turning in 1848, as well as about the West Indian colonies which were by then obviously becoming unbeneficial after the elimination of slavery. St. John, the East Indian messenger who is given the last words inJane Eyre, writes them as he is fading - slaughtered by the "insalubrious" ambience of repression in British India, as Rochester just misses declining when his West Indian plague-house falls down on him. Bronte's worry about British colonialism is all over the place perceptible in the ending of Jane Eyre. This novel is at length incapable to rest effortlessly in its metaphorical stratagem and its conventional anti-colonial political affairs: its antagonism to a "contaminating" and selfdestructive alliance with the subjugated colonies, and its encouragement of a middle-class domesticity freed from some of the most unconcealed forms of gender and class repression. Jane Eyre is thus an enthralling instance of the connections - and disconnections - between a confrontation to the principles of phallocentric monopoly and a confrontation to the principles of colonial power.

\section{ACKNOWLEDGEMENT}

We express our extreme gratitude and heartfelt thankfulness to Respected Professor Dr. Saunak Samajdar (Head of the Department, Department of English, Cooch Behar Panchanan Barma University) and Respected Military Historian, Dean (Students' Welfare, Raiganj University) as well as the Head of the Department of English, Raiganj University Professor Dr. Pinaki Roy for their blessings and inspiration which always inspire us in our literary venture. We are also thankful to Respected Teacher-in-charge of Lilabati Mahavidyalaya Professor Dr. Narayan Chandra Basunia, Professor Dr. Bijaya Kumar Biswal (Head of the Department, Department of Education, Lilabati Mahavidyalaya) and Professor Sanghamitra Mookherjee (Head of the Department, Department of English, Lilabati Mahavidyalaya) for their unconditional love and motivation.

\section{REFERENCES}

[1] Bronte, Charlotte. Jane Eyre. Penguin Books, 1847.

[2] Bronte, Charlotte. Shirley. Oxford University Press, 1849.

[3] Alexander, Christine. The Early Writings of Charlotte Bronte. Basil Blackwell, 1983.[

[4] Eagleton, Terry. Myths of Power: A Marxist Study of the Brontes. Barnes and Noble, 1975.

[5] Webb, Igor. From Custom to Capital: The English Novel and the Industrial Revolution. Cornell University, 1981.

[6] Bronte, Charlotte. Villette. Penguin Books, 1853.

[7] Spacks, Patricia Meyer. The Female Imagination. Knopf, 1972.

[8] Bhabha, Homi K. The Location of Culture. Routledge, 1994.

[9] Cecil, David. Early Victorian Novelists. Collins, 1970. 
[10] Morton, Stephen. Gayatri Chakravorty Spivak. Routledge, 2003.

[11] Nanni, Giordano. The Colonisation of Time: Ritual, Routine and Resistance in the British Empire. Manchester University Press, 2012.

[12] "Jennifer Lopez - Ain't Your Mama." YouTube, uploaded by Jennifer Lopez. 6 May 2016, www.youtube.com/watch?v=Pgmx7z49OEk. Accessed 20 January 2020. 